\title{
İçgrup Kimlikle Özdeşleşmenin Dışgrup Tutumlar ve Davranışsal Eğilimler Üzerinde Etkisi: Kıbrıs ve Türkiye Örneği
}

\author{
Sabahat Çiğdem Bağc1 ${ }^{1}$ \\ Sabancı Üniversitesi
}

\author{
Şenel Hüsnü Raman² \\ Doğu Akdeniz Üniversitesi
}

\begin{abstract}
Özet
Bu çalışmanın amacı içgrup kimliğiyle özdeşleşmenin dışgruba yönelik tutum ve davranışsal eğilimler (yaklaşma-kaçınma) üzerindeki etkisini iki farklı sosyo-kültürel bağlamda incelemek ve bu ilişkilerde dışgrubun bakış açısını alma ve algılanan tehdit değişkenlerinin aracı etkilerine bakmaktır. Birinci çalışma Türk kimliği ile özdeşleşmenin Kıbrıslı Türklerin Rumlara yönelik tutum ve davranışsal eğilimlerinde etkilerini incelerken, ikinci çalışma Türk kimliği ile özdeşleşmenin Türkiyeli Türklerin Suriyelilere yönelik algılarındaki etkisini araştırmıştır. Çalışmanın bulguları Kıbrıs bağlamında özdeşleşmenin Rumlara yönelik bakış açısını almayı azaltarak bu gruba dair tutum ve davranışsal eğilimleri olumsuz hale getirdiğini gösterirken, Türkiye bağlamında özdeşleşmenin Suriyelilere yönelik gerçekçi tehdit algısını azalttığını, bunun da bu gruba dair tutum ve davranışsal eğilimleri olumlu yönde etkilediğini göstermiştir. Sonuçlar sosyal kimlik kuramları 1şı̆̆ında tartışılmış, içgrup kimliğiyle özdeşleşmenin çok yönlü etkileri ve sosyo-kültürel bağlama göre değişkenliği değerlendirilmiştir.
\end{abstract}

Anahtar kelimeler: İçgrup kimlikle özdeşleşme, dışgruba yönelik tutumlar, davranışsal eğilimler, bakış açısı alma, algilanan tehdit, Suriyeliler, Rumlar

\begin{abstract}
The current study aimed to examine the effect of ingroup identification on outgroup attitudes and behavioral tendencies (approach and avoidance) in two different socio-cultural contexts. We further tested the mediational role of both outgroup perspective-taking and perceived threat in these relationships. While Study 1 investigated the role of Turkish ingroup identification on Turkish Cypriots' attitudes and behavioral tendencies toward Greek Cypriots, Study 2 explored the role of Turkish ingroup identification on Turkish citizens' attitudes and behavioral tendencies towards Syrian refugees in Turkey. Findings demonstrated that identification in the context of Cyprus resulted in decreased perspective-taking towards Greek Cypriots and thereby led to more negative outgroup attitudes and behavioral tendencies. On the other hand, identification in the context of Turkish citizenship led to decreased realistic threat which in turn led to more positive outgroup attitudes and behavioral tendencies. Findings are discussed in the light of social identity theories, multidimensional function of ingroup identification and its variability across different socio-cultural contexts.
\end{abstract}

Keywords: Ingroup identification, outgroup attitudes, behavioral tendencies, perspective-taking, perceived threat

Yazışma Adresi: ${ }^{1}$ Doç. Dr. Sabahat Çiğdem Bağcı, Sabancı Üniversitesi, Sanat ve Sosyal Bilimler Fakültesi, Psikoloji Bölümü, 34956 Tuzla / İstanbul, cigdem.bagci@sabanciuniv.edu, ORC-ID: 0000-0003-1642-2067

${ }^{2}$ Prof. Dr., Doğu Akdeniz Üniversitesi, Fen ve Edebiyat Fakültesi Gazimağusa, Kuzey Kıbrıs, shenelhusnu.raman@emu.edu.tr, ORC-ID: 0000-0001-5679-5568

Gönderim Tarihi: 15.11 .2018

Kabul Tarihi: 25.05 .2019 
Son yıllarda artan çokkültürlülük, etnik çeşitlilik ve göç gibi süreçler sonucunda birçok toplum artık tek bir grubu temsil etmek yerine, sosyal, politik ve ekonomik açılardan farklı konumlarda yer alan azınlık ve çoğunluk grup üyelerini bir arada barındırmaktadır. Bunun sonucunda er ya da geç ortaya çıkan gruplararası çatışma, anlaşmazlık ve ayrılıklar yıllardan beri birçok farklı grup bağlamında sosyal psikologların en çok çalıştığ konulardan biri olmuştur. Bu konudaki sosyal-psikolojik araştırmalar gruplararası çatışmaların grup üyelerinde yalnızca fiziksel kayıplarla sonuçlanmadığını, psikolojik anlamda da toplumun her katmanına yayılarak bireylerin iç ve dışgruplara yönelik algılarını yönlendirdiğini göstermektedir (örn. Bar-Tal, 2010; Brewer, 2001; Hewstone ve Greenland, 2000; Jackson, 2002; Uluğ ve Cohrs, 2017). Üstelik sadece süregelen çatışmalar değil, geçmişte yaşanan çatışmalar da grupların kolektif belleklerini oluşturmakta ve günümüzdeki gruplararası ilişkilerin belirlenmesinde önemli rol oynamaktadır (Bar-Tal, 2007). Bu da gruplararası tutum ve davranışların olumlu yönde geliştirilmesi ve sonucunda toplumsal barışın sağlanması için farklı grup dinamiklerinin incelenmesinin hem kuramsal, hem de uygulamalı anlamda önemini vurgulamaktadır. Bu çalışmanın temel amacı iki farklı gruplararası bağlam üzerinden (Kıbrıslı Türklerin Kıbrıslı Rumlara, Çalıșma 1; Türkiyeli Türklerin Suriyelilere, Çalışma 2) içgrupla özdeşleşmenin dişgruplara yönelik tutum ve davranışsal eğilimlerde etkisini deneysel bir araştırma deseni ile test etmek, aynı zamanda bu etkilerde dışgrubun bakış açısını alma ve tehdit kavramlarının aracı rolünü incelemektir.

\section{İçgrup kimlikle özdeşleşme ve dışgruba yönelik tutum ve davranışlar}

Çatışma toplumlarının en önemli özelliklerinden biri grup üyeliklerinin algısal olarak belirgin olması ve kişilerin kimliklerinde tanımlayıcı bir rol oynamasıdır (örn. Bar-Tal, 2007). Yapılan araştırmalar özellikle olumsuz gruplararası tutumların oluşmasında içgrup kimlikleriyle yoğun şekilde özdeşleşmenin önemli bir rolü olduğunu varsaymaktadır. Gruplararası dinamiklerin araştırılmasında en sık sözü edilen kuramlardan biri olarak Sosyal Kimlik Kuramı (Tajfel ve Turner, 1979), kişilerin içgrup kimlikleriyle özdeşleşmelerinin benlik algılarını arttırmaya yönelik bir süreç olduğunu, bunun sonucunda da kişilerin kendi gruplarını diğer gruplardan kayırmaya yöneldiklerini belirtmektedir (ingroup favouritism; Brewer, 1999; Hinkle ve Brown, 1990; Jackson, 2002). Buna göre kuram, içgrupla özdeşleşmenin dişgrup tutum ve davranışlar ile olumsuz yönde ilişkili olacağını öne sürmektedir. Nitekim bu öneri birçok görgül araştırmada bulgulanmıştır. Örneğin, Hollanda'da yapılan araştırmalar Hollandalı vatandaşların azınlık gruplarına yönelik olumlu tutumlarının içgrup kimliklerinin güçlenmesi ile azaldığını göstermiştir (Masson ve Verkuyten, 1993; Sniderman ve Hagendoorn, 2007; Verkuyten, 2006; Verkuyten ve Brug, 2004). Pehrson, Brown ve Zagefka (2011), ulusal kimliklerle özdeşleşmenin, özellikle 'etnik' özellikler vurgulandığında, göçmen gruplara yönelik olumsuz tutumları arttırdığını bulmuştur. Türkiye'de Türk ve Kürt gruplararasında uygulanan bir çalışmada ise, etnik grupla özdeşleşmenin gruplararası çatışma algısı ve dışgruba sorumluluk yüklemeyi arttırdığı, bu değişkenlerin de dişgruba yönelik tutumlar ile olumsuz bir şekilde ilişkili olduğu belirtilmiştir (Bagci ve Çelebi, 2017a).

$\mathrm{Bu}$ alanda yürütülen diğer bir çalışma grubu ise içgrup kimliğiyle özdeşleşme ile dişgruba yönelik tutum ve davranıșlar arasında doğrudan bir ilişki olmadığını öne sürmektedir. Örneğin, Brewer'a $(1999,2001)$ göre "içgruba duyulan sevgi" ile "dişgruba duyulan nefret" arasında doğrudan bir ilişki yoktur. Yani, içgruba duyulan olumlu duygular ve özdeşleşme doğrudan dişgrubu dışlama ve dişgruba olumsuz yaklaşmaya sebep olmamakta; dışgruba yönelik olumsuz tutum ve davranışların ardındaki en büyük motivasyon dişgruba duyulan düşmanlıktan ziyade içgrubu dişgruba kayırmaktır. Örneğin, Mummendey, Klink ve Brown'in (2001) Almanya ve İngiltere'de uyguladıkları deneysel araștırmalarda, Alman ve İngiliz vatandaşlarının ulusal kimlikleriyle özdeşleşmeleri ile dışgrubu reddetmeleri arasındaki ilişkinin yanlızca gruplararası karşılaştırmanın belirginleştirildiği durumlarda ortaya çıktığı gösterilmiştir. Başka bir çalışmada, Lyons, Kenworthy ve Popan (2010) Amerikalıların Araplara yönelik tutum ve davranışlarının doğrudan içgrup kimlikleri tarafindan yordanmadığını; içgrup kimliğiyle özdeşleşmenin yalnızca grup seviyesinde narsistlik duyguları orta ve güçlü seviyede olan kişiler arasında olumsuz tutumlar ile ilişsili olduğunu göstermiştir. Verkuyten ve Nekuee'nin (1999) çalışmasında da içgrupla özdeşleşme ile içgruba yanlılık arasında doğrudan bir ilişki bulunmamışken, içgrup kimliğiyle özdeşleşmenin öz-kalıpyargılarla etkileşiminin içgruba yanlılığı yordadığ1 görülmüştür.

Bunun da ötesinde, bazı çalışmalar içgrup kimliğiyle özdeşleşmenin sonucunda kişilerin dişgruplara karş1 daha güvenli ve toleranslı olabileceğini önesürmüştür (Berry, 1984; Phinney, 1993). Örneğin, Phinney, Ferguson ve Tate (1997) etnik kimlikle özdeşleşmenin daha olumlu içgrup tutumların oluşmasını sağladığını, bunun da dışgrup tutumlarıyla olumlu olarak ilişkili olduğunu bulgulamıştır. Diğer bir çalışmada Phinney, Jacoby ve Silva (2007) olgunlaşmış (başarılı) bir etnik kimliğe sahip bireylerin (achieved ethnic identity; Phinney, 1989) kimlik arayışı ve bununla ilgili kimlik krizini aşmış ve seçilen kimliğe güvenli bir şekilde bağlanmış 
kişiler olacağını (Phinney, 1989), dolayısıyla da hem kendi gruplarına hem de dışgruplara daha hoşgörülü ve anlayışlı yaklaşabileceklerini vurgulamıştır. Nitekim, Phinney ve arkadaşları Asyalı ve Latin Amerikalı öğrenciler arasında yaptıkları çalışmada, etnik kimliklerine güvenli bir şekilde bağlı kişilerin diğer gruplara karşı daha 1lımlı ve anlayışıı olduğunu, gruplararası ilişkilerde daha bilinçli olduğunu, sonucunda da dişgruplara daha olumlu tutumlar sergilediğini göstermiştir. Bu bakış açısına göre, içgrup kimliğiyle özdeşleşmenin sosyal kimlik kuramının öne sürdüğü gibi dışlayıcı rolünün aksine, kişileri daha az etno-merkezci yapan ve dişgruba yönelik olumlu tutumları destekleyen bir süreç olduğu söylenebilir. Tüm bu bulgular ışı̆̆ında, içgrup kimliğiyle özdeşleşmenin dışgrup tutumları ve davranışsal eğilimler üzerindeki etkisinin farklı gruplararası bağlamlarda farklı şekillerde gerçekleşebileceği görülmektedir.

\section{Dışgrubun bakış açısını alma ve algılanan tehdit}

$\mathrm{Bu}$ çalışma içgrup kimliğiyle özdeşleşmenin dışgruplara yönelik tutumlardaki ve davranışsal eğilimlerdeki etkisini iki farklı aracı değişken - dışgrubun bakış açısını alma (perspective-taking) ve algılanan tehdit (perceived threat) - üzerinden incelemeyi hedeflemektedir. Dışgrubun bakış açısını alma, yani kendini dışgrup üyelerinin yerine koyabilme, gruplararası ilişkiler literatüründe olumlu gruplararası süreçlerin oluşmasında önemli bir yordayıcı olarak gösterilmektedir (örn. Batson ve ark., 1997; Pettigrew ve Tropp, 2008; Vescio, Sechrist ve Paolucci, 2003). Özellikle çatışma hissedilen çevrelerde dışgrubun bakış açısını alma ve dışgrup üyelerine empati duymanın, dişgruba merhamet duyma ve gruplararası çatışma konusunda daha çok sorumluluk alma (Zebel, Doosje ve Spears, 2009), dişgrubu affetme (Cehajic, Brown ve Castano, 2008) ve çok kültürlülüğe destek (Todd ve Galinsky, 2012) ile ilişkisinin olumlu olduğu; rekabetçi mağduriyet algısı (Andrighetto, Mari, Volpato ve Behluli, 2012), genel önyargilı tutumlar (Levin, Luoma, Vilardaga, Lillis, Nobles ve Hayes, 2016), açık ve örtük önyarg1 (Aberson ve Haag, 2007; Bagci ve Birinci, 2017) gibi olumsuz gruplararası süreçler ile ise olumsuz şekilde ilişkilendirildiği görülmektedir. Farklı çalışmalar ise diğer grubun bakış açısını almanın tutumlar üzerinde etkisini deneysel araştırma yöntemleriyle bulgulamıştır. Örneğin, Galinsky ve Moskowitz (2000), bakış açısını almanın arttırıldığ rol grubuna göre, dışgrup üyelerini daha olumlu değerlendirdiğini göstermiştir. Kıbrıs'ın kuzeyinde yapılan bir çalışmada, Kıbrıslı Rumlarla temas kurgulayan Kıbrıslı Türklerin tutumlarının kontrol grubuna göre daha olumlu hale geldiği görülmüş; bu etkinin dışgrubun bakış aç1sını alma değişkeni tarafindan açıklandığı bulunmuştur (Husnu ve Crisp, 2015).
Dışgrubun bakış açısını almanın aksine, dışgruba dair hissedilen tehdit algısı gruplararası süreçleri olumsuz yönde etkilemektedir. Gerçekçi Grup Çatışması Kuramı'na (Realistic Conflict Theory; Sherif, Harvey, White, Hood ve Sherif, 1961) göre, gruplararası çatışma ve olumsuz tutumlar grupların sınırlı sayıda kaynakları elde etmek için sarfettiği mücadelenin sonucunda oluşmaktadır. Böylece, gruplar diğer dış grupların bu kaynakları elde edebileceği endişesini taşır ve tehdit hisseder. Çalışmalar hissedilen tehdit algısının yalnızca gerçekçi/ materyalist kaynaklar üzerinden değil, sembolik değerler üzerinden de (din, dil, kültür gibi) tecrübelenebileceğini göstermektedir. Gruplararası tehdit konusunda yürütülen görgül çalışmalar, dışgruba dair hem gerçekçi hem de sembolik tehdit algisının gruplararası tutumlar (Stephan ve ark., 2002; Tausch, Tam, Hewstone, Kenworthy ve Cairns, 2007; Ward ve Masgoret, 2006) ile açık ve örtük önyargıy1 (Aberson ve Gaffney; Gonzalez, Verkuyten, Weesie ve Poppe, 2008) yordadığını birçok farklı gruplararası bağlamda göstermiştir. Riek, Mania ve Gaertner (2006) 95 çalışmalık bir meta-analizde (çoğunlukla Kuzey Amerika, Kanada ve İngiltere gibi ülkelerdeki araştırmaların dahil olduğu) farklı türdeki tehdit algılarının (gerçekçi, sembolik, gruplararası kayg1, ...) gruplararası tutumlar ile olumsuz ilişkisini göstererek, algılanan tehdit kavramının gruplararası tutumlardaki belirleyici rolünün altını çizmiştir. Türkiye'de yapılan bir çalışmada da, Türklerin Kürt ve Ermeni gruplarına yönelik algıladıkları tehdidin bu gruplara yönelik tutumları yordamada önemli bir değişken olduğu bulgulanmıştır (Bagci ve Çelebi, 2017b).

\section{Gruplararası temas}

Gruplararası Temas Kuramı (Allport, 1954; Pettigrew, 1997), özellikle eşit statü ve ortak amaç paylaşımı gibi kritik koşullar sağlandığında, temasın olumsuz dışgrup süreçlerini azaltacağını ortaya atmaktadır. Pettigrew ve Tropp (2006) gruplararasi temas kuramının etkinliğini incelemek amacıyla yaptıkları ve 500'den fazla görgül araştırmayı ele aldıkları meta-analiz çalışmasında, temasın önyargı ile olumsuz bir şekilde ilişkili olduğunu ortaya koymuştur. Alanda yapılan birçok çalışma gruplararası temasın farklı etnik ve ırksal gruplara karşı olumsuz tutum ve davranışları azaltmanın ötesinde, dezavantajlı konumdaki diğer gruplara (örneğin, eşcinsel bireyler, Herek ve Capitanio, 1996; akıl hastaları, Link ve Cullen, 1986; fiziksel engelliler, Maras ve Brown, 2000; göçmenler, Voci ve Hewstone, 2003; ve yaşlilar, Abrams, Eller ve Bryant, 2006 gibi) yönelik tutumları da iyileştirebileceğini bulgulamıştır.

Gruplararası temas çalışmamızda kullanılan iki sosyo-kültürel çevrede daha önce çalışılmış ve temasın olumlu etkilerine rastlanmıştır (Kıbrıs için örn. Husnu ve Crisp, 2010, 2015; Husnu, Mertan ve Onay, 2018; Husnu 
ve Paolini, 2019; Stathi, Husnu ve Pendleton, 2017; Yucel ve Psaltis, 2019; Türkiye için örn. Bagci ve Çelebi, 2017a; Bagci, Piyale, Bircek ve Ebcim, 2018; Bagci, Piyale, Sen ve Yildirim, 2019; Bagci, Stathi ve Piyale, 2019; Bagci ve Turnuklu, 2019). Dolayısıyla gruplararası temas çalışmamızda bir kontrol değişkeni olarak ele alınmıştır.

\section{Çalışmanın katkıları ve hipotezler}

Sonuç olarak, çalışmamızın gruplararası ilişkiler alanyazınına katkıları şu şekilde özetlenebilir. Öncelikle, içgrup kimliğiyle özdeşleşmenin dişgruplara yönelik tutum ve davranışlar ile ilişkisi daha önceki çalışmaların bir çoğunda korelasyonel yöntemlerle incelenmiş, bu sebeple özdeşleşme-tutumlar arasındaki nedensellik olgusunu yansıtamamıştır (örn. Masson ve Verkuyten, 1993; Mummendey ve ark., 2001; Pehrson ve ark., 2011). Bunun yanında, çalışmamız iki farklı sosyo-kültürel çevreyi ele almış; Kıbrıs’taki Türk-Rum ve Türkiye'deki Türk-Suriyeli gruplararası ilişkilerine değinerek içgrup kimlikleriyle özdeşleşmenin dişgruplara yönelik tutum ve davranışları nasıl etkilediğini iki farklı bağlamda incelemiştir. Ek olarak, çalıșmanın bulguları her iki kültürel bağlamda sosyal politikaları belirleyici bir rol oynayabilir; çalışmamızın sonuçları özellikle Kıbrıs'taki segregasyonun azalması ile Türk ve Rum Kıbrıslılar arasında olumlu temas süreçlerinin başlatılması, Türkiye'de ise Suriyeli göçmenlere yönelik ılımlı yaklaşımların arttırılması ve bu grubun Türkiye'ye başarılı bir şekilde uyum sağlaması için uygulanacak programların hazırlanmasında yol gösterici olacaktır.

Yukarıdaki bulgular 1şı̆̆ında içgrup kimliğiyle özdeşleşmenin grup üyelerini iki farklı şekilde etkileyebileceği düşünülebilir. Sosyal kimlik kuramından yola çıkılarak, içgrup kimliğiyle özdeşleşen bireylerin diğer gruplara göre kendi gruplarını daha üstün göreceği ve sonucunda diğer grupların bakış açısını almada zorlanacağı beklenebilir. Bu öneriyi destekleyecek şekilde daha önceki görgül çalışmalar içgrup kimliğiyle özdeşleşme ile etno-merkezci bakış açısının olumlu şekilde ilişkili olduğunu göstermiştir (Perreault ve Bourhis, 1999). Aynı şekilde içgrup kimliği ile özdeşleşmenin grup farklılıklarını daha belirgin hale getireceği, bunun da algılanan tehdidi arttıracağ1 öne sürülebilir. Bu konudaki görgül çalışmaların bir kısmı içgrup kimliğiyle özdeşleşmeyi tehdit algısının tutumlar üzerindeki etkisinde düzenleyici bir değişken olarak ele almış olsalar da (Bizman ve Yinon, 2001; Tausch ve ark., 2007), diğer çalışmalar özdeşleşme ile tehdit algısı arasındaki doğrudan ve olumlu ilişkileri göstermektedir (Stephan ve ark., 2002). Böylece içgrupla özdeşleşme sonucunda bireylerde dışgrubun bakış açısını alma azalırken algilanan tehdit artacak, bunun sonucunda da tutumlar ve davranışlar olumsuz yönde etkilenecektir (Hipotez 1). Öte yandan Brewer'ın (1999) bahsettiği gibi içgrup kimliğiy- le özdeşleşme kayıtsız şartsız dişgruba olumsuz tutum ve davranışları beraberinde getirmeyebilir. Phinney ve arkadaşlarının (2007) savunduğu gibi içgrup kimliğiyle özdeşleşme kişilerde grup üyeliklerinin daha iyi anlaşılması ve diğer gruplara empati duyulmasını sağlayabilir. Özdeşleşmenin aynı zamanda bireylerde grup seviyesindeki öz-güvenin artması ile ilişkili olacağı düşünüldügüunde, dişgrubun bakış açısını almayı arttıracağı ve algılanan tehdidi azaltacağı, sonucunda da tutum ve davranışsal eğilimleri olumlu yönde etkileyeceği beklenebilir (Hipotez 2). Araştırmamızda bu iki karşıt hipotez deneysel bir desen kullanilarak test edilmektedir.

\section{Birinci Çalışma}

Birinci çalışma, Kıbrıs’ta yürütülmüş olup, Kıbrıs11 Türklerin Kıbrıslı Rumlara karşı tutum ve davranışsal eğilimlerini ölçmeyi hedeflemektedir. Tarihsel anlamda birçok çatışma sürecinden geçmiş olan Kıbrıs, yıllardan beri Kıbrıslı Türk ve Kıbrıslı Rumların fiziksel anlamda bir arada yaşadı $\breve{g}$, ancak gruplararası sosyal temasın halen asgari seviyede tecrübe edildiği benzersiz bir gruplararası bağlam oluşturmaktadır (Husnu ve Crisp, 2010). Kuzey ve Güney Kıbrıs arasında geçişler 2004 yılında serbest birakılmasına rağmen, Psaltis ve Lytras'a (2012) göre, Kıbrıslı Türklerin \%22.81'i Kıbrıslı Rumların ise \%32.87'si adanın 'öteki' yarısına henüz geçmemiştir. Kıbrıslı Rumların geçiş yapmama nedenlerini araştıran başka bir çalışmada, Kıbrıslı Rumların \%57'sinin Kuzey Kıbrıs'a geçmenin 'uygunsuz' olduğunu; Kuzey Kıbrıs Türk Cumhuriyeti'nin siyasi varlığını dolaylı olarak tanıma ve ekonomisine destek verme gibi olumsuz olduğu düşünülen sebepleri ortaya koymuştur (Webster ve Timothy, 2006). Buna rağmen, Kıbrıslı Türk yetişkinlerle yapılan temas çalışmalarında, temasın Kıbrıslı Rumlara karşı önyargıyı azalttığı (Husnu ve Lajunen, 2015), olumlu davranışsal eğilimleri (Husnu ve Paolini, 2019) ve affetmeyi arttırdığı (Stathi ve ark., 2017) bulgulanmıştır. Kıbrıslı Türk çocuklarla yapılan çalışmalarda ise temasın Kıbrıslı Rumlara karşı güveni arttırdığı saptanmıştır (Husnu, Mertan ve Cicek, 2016). Kıbrıslı Rumlarla yapılan çalışmalarda da temasın benzer olumlu sonuçları bulunmuştur (Iaonnou, 2009; Tausch ve ark., 2010).

İçgrupla özdeşleşmenin Kıbrıs bağlamındaki yeri, Kıbrıs Sorunu ile yakından ilişkili olduğu için önem arz etmektedir. Vural ve Rustemli (2006) Kıbrıslı Türklerin 'kimlik dalgalanmalarını' araştırmış ve Kıbrıs Sorunu ile ilişkisine bakmıştır. 'Türklük' veya 'Müslümanlık' kimlikleriyle daha fazla özdeşleşen katılımcılar iki ayrı devlet yapısını benimserken, 'Kıbrıslı' kimliğiyle özdeşleşenlerinse adanın tek bir devlet veya 'federal çözüme' olumlu baktığını bulgulamıştır. Bu bağlamda bu çalışma Kıbrıslı Türklerin Kıbrıslı Rumlara karşı tutum ve dav- 
ranışsal eğilimlerini ölçmek ve içgrupla özdeşleşmenin rolünü saptamayı hedeflemektedir.

Çalışmamızda tutumların yanı sıra Kıbrıslı Rumlara yönelik davranışsal eğilimler de bağımlı değişken olarak ele alınmaktadır. Son yıllardaki çalışmalar özellikle gruplararası literatürde yaklaşma - kaçınma davranışsal eğilimlerinin gruplararası ilişkilerin düzenlenmesinde önemli rol oynadığını göstermektedir (Wyer, 2010). Çalışmalarda dişgruplara yönelik bu tür davranışsal eğilimlerin her ne kadar otomatik bir süreç olduğundan bahsedilse de, bir çok deneysel çalışmada anlık sosyal durumun dışgruba dair davranışsal eğilimleri değiştirebileceği gösterilmiştir. Örneğin, eşitlikçi normların belirgin hale getirildiği durumlarda (Wyer, 2010), ya da temasın kurgusal olarak hayal ettirildiği durumlarda (örn. Turner, West ve Christie, 2013) dişgruba yönelik davranışsal eğilimlerin daha çok yaklaşmacı ve daha az kaçınmacı olduğu görülmüştür.

\section{Yöntem}

\section{Örneklem ve İșlem}

Çalışmaya toplamda 117 kişi katılmıştır (55 Kadın, 62 Erkek). Katılımcıların yaşları 18-79 arası değişmekte olup yaş ortalaması $31.22(S S=11.04$, Ranj $=18-79)$ olarak belirlenmiştir. Katılımcılara uyruk sorulduğunda 107 kişi Kuzey Kıbrıs Türk Cumhuriyeti'ni (KKTC) işaretlemiş, 8 kişi ise KKTC ile Türkiye Cumhuriyeti seçmiştir (2 kişi ise uyruk belirtmemiştir).

Katılımcılar Kuzey Kıbrıs'ın çeşitli şehir ve kasabalarından (Lefkoşa, Gazimağusa, Girne, Güzelyurt gibi) çevrimiçi ve kağıt-kalem yöntemi ${ }^{1}$ ile anketleri doldurmuşlardır (Temmuz 2018). Çevrimiçi anketler, sosyal medya platformları (Facebook, Twitter ve Messenger gibi) üzerinden ve elektronik posta yöntemiyle dağıtılmıştır. Kağıt-kalem yöntemi ile doldurulan anketler ise kar topu yöntemi ile seçkisiz örnekleme ile toplanılmıştır. Katılımcılar onam formunu doldurduktan sonra deneysel prosedüre katılmışlardır. Katılımcılar kontrol grubuna $(n=59)$ ve deneysel gruba $(n=58)$ rastgele şekilde atanmıştır. Kontrol grubundaki katılımcılardan en son yaptıkları tatili hayal etmeleri ve bununla ilgili bazı detayları hatırlamaları istenmiştir:

"Lütfen en son yaptığınız tatili hatırlamaya çalışın. Sizden bu anının detaylarını hatırlamanızı istiyoruz. Bu anıyı ne zaman, nerede ve kiminle yaşad1nız? Lütfen bu tecrübeyle ilgili gözlemlerinizi ve neler hissettiğinizi detaylarıyla anlatın."

Deneysel grupta ise katılımcılardan Kıbrıslı Türkler ile ilgili kendilerini gururlandıran ve mutlu eden bir anıyı hatırlamaları istenerek, katılımcıların içgrup kim- liğiyle özdeşimlerini arttırma hedeflenmiştir. Bu prosedür daha önce Sassenberg ve Wieber (2005) tarafindan kullanılmış, araştırmacılar bu manipülasyonun sonucunda katılımcıların içgruplarıyla özdeşimlerinin arttığını bulmuşlardır. Orijinal çalışmada bu manipülasyon genç-yaşlı gruplararası bağlamında kullanılmıştır. Bu çalışmada ise içgrupla özdeşleşme ulusal kimlikler üzerinden tanımlanmıştır:

"Lütfen Kıbrıslı Türkler ile ilgili sizi gururlandıran ve mutlu eden bir anınızı hatırlamaya çalışın (örnek: Kıbrıslı Türkler'in bir yarışmada galip gelmesi veya bir alanda başarı elde etmesi,..). Lütfen bu durumun tek bir Kıbrıslı Türk ile ilgili olmamasına, birçok Kıbrıslı Türkü ilgilendiren bir olay olmasına dikkat edin. Eğer böyle bir anı aklınıza gelmiyorsa, lütfen hayali bir şekilde zihninizde canlandırın. Sizden bu anının detaylarını hatırlamanızı istiyoruz. Bu anıyı ne zaman, nerede ve kiminle yaşad1nız? Lütfen bu tecrübeyle ilgili gözlemlerinizi ve neler hissettiğinizi detaylarıyla anlatın."

\section{Manipülasyon kontrolü}

Kullanılan manipülasyonun beklenen doğrultuda çalışıp çalışmadığını görmek için manipülasyonun ardından katılımcılara iki madde ile içgrup kimlikleriyle ne derece özdeşleştikleri sorulmuştur ("Kıbrıslı Türklere bağl11ık duyarım" ve "Kıbrıslı Türk olduğumu hissederim"; $1=$ Kesinlikle katılmıyorum, 7 = Kesinlikle katılıyorum). $\mathrm{Bu}$ iki madde daha önceki içgrup kimliğiyle özdeşleşme ölçeklerinde üzerinde durulmuş ve kimliğe bağlılık ile aidiyet kavramlarını ölçmektedir (örn. Verkuyten, 2005). Kullanılan iki maddenin oluşturduğu ölçeğin güvenirliği yüksek bulunmuştur $(r=.74, p<.001)$. Uygulanan bağımsız iki örneklem t-testi sonuçlarına göre, kontrol grup (Ort. $=3.75, S S=1.64)$ ile özdeşleşme grubu (Ort. $=4.42, S S=1.99)$ arasında anlamlı bir farklılık olduğu, özdeşleşme grubundaki katılımcıların kontrol grubundakilere göre Kıbrıslı Türk grubu ile daha yüksek seviyede özdeşleştikleri bulgulanmıştır, $t(115)=1.98, p=.05$.

\section{Veri Toplama Araçları}

Kontrol değişkenleri. Önceki çalışmalar temas seviyesi ile dışgrup tutum ve davranışları arasında güçlü bir bağlantı olduğunu göstermiştir (Gruplararası Temas Kuram1; Allport, 1954; Pettigrew, 1997; Pettigrew ve Tropp, 2006). Bu bağlamda, katılımcılara Kıbrıslı Rumlarla günlük temas seviyesinin ("Günlük hayatınızda ne sıklıkla Kıbrıslı Rumlarla olumlu geçen görüşmeleriniz olur?"; Barlow ve ark., 2012) ve temas kalitesinin (üç madde: "Kıbrıslı Rumlarla olan temasınız ne derece: yakın, işbirlikçi ve keyifli buluyorsunuz?"; Voci ve Hews-

1 Örneklem üzerindeki kontrol sağlandıktan sonra çevrimiçi ve kağıt-kalem veri toplama yöntemleri arasında anlamlı farklar gözlemlenmemektedir (Riva, Teruzzi ve Anolli, 2003). 
Tablo 1. Kontrol ve Özdeşleşme Grubu için MANCOVA Modeli

\begin{tabular}{lcccc}
\hline & Kontrol grubu & Özdeşleşme grubu & $F$ & $p$ \\
\hline Dişgrubun bakış açısını alma & $5.54(.16)$ & $5.07(.16)$ & 4.29 & .04 \\
Algılanan tehdit & $4.79(.14)$ & $4.54(.14)$ & 1.64 & .20 \\
Dişgruba yönelik tutumlar & $7.54(.23)$ & $7.04(.23)$ & 2.31 & .13 \\
Dişgruba yönelik yaklaşma eğilimi & $5.87(.17)$ & $5.66(.17)$ & .75 & .39 \\
Dışgruba yönelik kaçınma eğilimi & $1.47(.16)$ & $1.96(.17)$ & 4.30 & .04 \\
\hline
\end{tabular}

Not. Düzeltilmiş ortalama değerleri ile standart hata değerleri (parantez içinde) belirtilmiştir.

tone, 2003, Cronbach alfa $=.84$ ) dişgruba yönelik tutum ve davranışsal eğilimleri güçlü bir şekilde yordayabileceği düşünülerek bu değişkenler de kontrol değişkeni olarak esas analizlere dahil edilmiştir.

Ana değişkenler için kullanılan ölçeklerde aksi belirtilmediği sürece cevap seçenekleri 1 (kesinlikle katılmıyorum) ile 7 (kesinlikle katıllyorum) arasında Likert tipi cevap ölçeği kullanılarak belirtilmiştir.

Dışgrubun bakış açısını alma. Dışgrubun bakış açısını alma ölçeği katılımcıların kendilerini ne derece Kıbrıslı Rumların yerine koyabildiklerini ve onların bakıș açılarını alabildiklerini ölçmektedir. Bu değișkeni ölçmek amacıyla Aberson ve Haag'ın (2007) bakış açısı alma ölçeği Türkçe'ye uyarlanarak, iki madde kullanılmıştır ("Kıbrıslı Rumları düşündüğümde olaylara onların bakış açısından bakabiliyorum" ve "Kıbrıslı Rumların dünya görüşlerini anlayabiliyorum”). Ölçeğin güvenilirliği uygun bulunmuştur $(r=.65, p<.001)$.

Algılanan tehdit. Kıbrıslı Rumlara yönelik algılanan tehdit yedi maddelik iki uçlu bir ölçekle ölçülmüş, katılımcıların Kıbrıslı Rumları farklı konularda ne derece tehdit edici-zenginleștirici buldukları belirtilmiștir (Florack, Piontowski, Rohmann, Balzer ve Perzig, 2003). Ölçek maddeleri hem gerçekçi tehdit (işsizlik ve ekonomi), hem de sembolik tehdit (dil, din, kültürel değerler, politik görüş) unsurları içermiştir ("Kıbrıslı Rumları din/dil/politik görüş/kültürel değerler/ișsizlik/ekonomi konusunda ne derece tehdit edici/zenginleştirici buluyorsunuz?, 1 = tehdit edici, 7 = zenginleştirici). Ölçeğin maddeleri hem sembolik hem de gerçekçi tehdit içerdiğinden yapılan doğrulayıcı faktör analizi sonuçlarında ölçek maddelerinin iki faktöre beklenildiği şekilde yüklenmemiş olmasından dolayı algılanan tehdit değişkeni tek bir değişken olarak analize katılmıştır (Cronbach alfa $=.65)$.

Dışgruba yönelik tutumlar. Kıbrıslı Rumlara yönelik tutumları ölçmek amacıyla tek maddelik duygu termometresi kullanılmıştır (Esses, Haddock ve Zanna, 1993). Katılımcılar Kıbrıslı Rumlara yönelik hissettikleri sıcaklık seviyesini açık uçlu olarak 0 (maksimum olumsuz) ile 10 (maksimum olumlu) derece arasında belirtmiştir.
Dışgruba yönelik davranışsal eğilimler. $\mathrm{Bu}$ çalışmada Kıbrıslı Rumlara yönelik yaklaşma ve kaçınma davranışları birer madde ile ölçülmüştür. Yaklaşma eğilimi için "Eğer seçme şansınız olsaydı Kıbrıslı Rumlarla ne derece daha fazla temas kurmak isterdiniz?", kaçınma eğilimi için ise "Kıbrıslı Rumlarla temas kurmaktan ne derece kaçındığınızı düşünüyorsunuz?” maddeleri kullanılmıştır (Mackie, Devos ve Smith, 2000). Türkçe'ye çevrilmiş hali daha önce Kıbrıs bağlamında yürütülmüş bir çalışmada kullanılmıştır (Husnu ve Paolini, 2019). İki madde arasında olumsuz, ancak orta seviyede bir korelasyonel ilişki $(r=-.26, p<.01)$ bulunduğundan iki madde ayrı ayrı değerlendirilmiştir.

\section{Bulgular}

\section{Grup farklılıkları}

İlk olarak iki grup arasındaki (kontrol-özdeşleşme) farklara bakmak amaciyla temas seviyesi ve temas kalitesininin kontrol değişkenleri olarak kullanıldığı ve alg1lanan tehdit, dışgrubun bakış açısını alma, tutumlar ile yaklaşmacı ve kaçınmacı davranışsal eğilimlerin bağımlı değişkenler olarak ele alındığı MANCOVA (Multivariate Analysis of Covariance) testi uygulanmıştır. Bulgular, kontrol değişkenlerinden yalnızca temas kalitesinin çoklu bir etkisinin olduğunu göstermiştir, $F(5,108)=16.69$, $p<.001, \eta^{2} p=.44$. Grubun çoklu etkisi anlamsızdır, $F(5,108)=1.61, p=.17, \eta^{2} p=.07$. Ancak tekli etkilere bakıldığında, grubun bakış açısını alma üzerinde etkisi olduğu görülmektedir, $F(1,112)=4.29, p=.04, \eta^{2} p=$ .04. Buna göre, özdeşleşmenin arttırıldığı deneysel grupta dişgrubun bakış açısını alma (Ort. $=5.07, S S=.16)$ kontrol grubuna (Ort. $=5.54, S S=.16)$ göre daha düşük seviyede belirtilmiştir. Ayrıca, özdeşleşmenin arttırıldı̆̆ 1 deneysel grupta dışgruba yönelik kaçınma eğilimi (Ort. $=1.96, S S=.17)$ kontrol grubuna göre artmıştır $($ Ort. $=$ $1.47, S S=.16), F(1,112)=4.30, p=.04, \eta^{2} p=.04$. Tablo 1 iki grup için düzeltilmiş ortalama (adjusted mean) ve standart hataları (standard error) göstermektedir. 


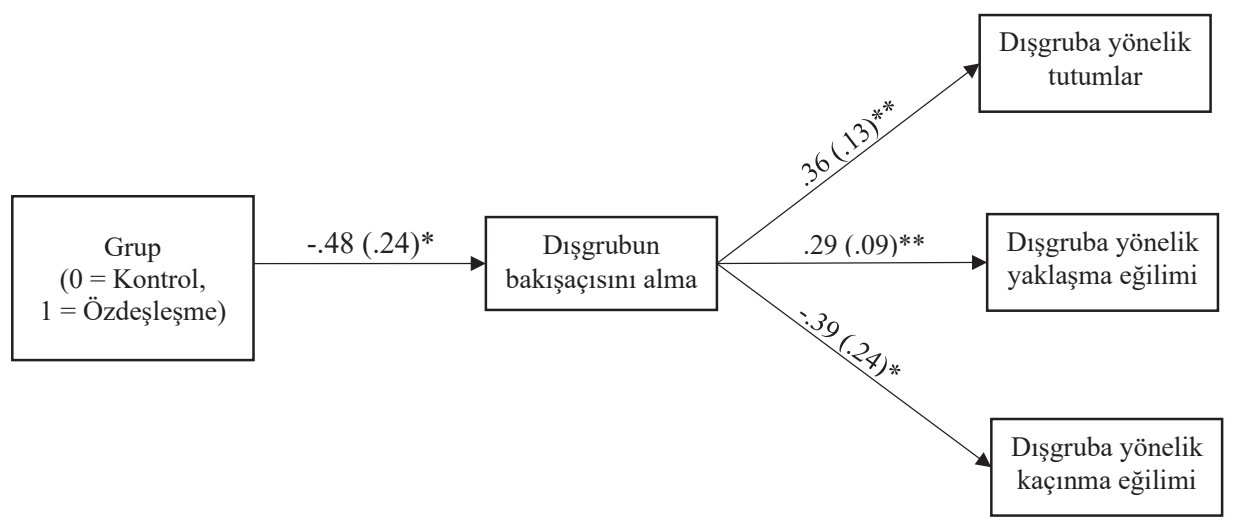

Not. $* p<.05, * * p<.01$. Standartlaştırılmamış katsayılar ve standart hata değerleri (parantez içinde) belirtilmektedir. Grubun bağımlı değişkenler üzerindeki doğrudan etkileri anlamsız olduğundan şekil üzerinde belirtilmemiştir.

Şekil 1. Birinci Çalışmada Grubun Tutumlar ve Davranışsal Eğilimler Üzerindeki Dolaylı Etkileri

\section{Aracı değişken analizi}

Çalışmamızın diğer bir araştırma sorusu içgrupla özdeşleşmenin tutumlar ve davranışsal eğilimler üzerindeki etkisinde dışgrup bakış açısı alma ve tehdit değişkenlerinin aracı rolünü anlamaktır. Ön analizlerde içgrupla özdeşleşmenin tehdit algısı değişkeni üzerinde anlamlı bir etkisi olmadığından bu değişken aracı olarak modele eklenmemiş, yalnızca bakış açısı alma değişkeni aracı olarak incelenmiştir. Aracı modellemede son yıllardaki çalışmalar aracı testinin yapılması için bağımsız değişken ile bağımlı değişken arasındaki ilişkinin gerekli olmadığ1 görüşündedir (Hayes, 2013). Böylece, grup değişkeninin tutumlar ve davranışsal eğilimler üzerindeki dolaylı etkisi, temas kalitesi kontrol değişkeni, grup değişkeni bağımsız değişken, bakış açısını alma arac1 değişken ve tutumlar ile yaklaşmacı ve kaçınmacı davranışlar bağımlı değişken olarak ele alınarak PROCESS Makrosu (Hayes, 2013, Model 4) ile test edilmiştir.

Kıbrıslı Rumlara yönelik tutumların bağımlı değişken olarak test edildiği ilk modelde, grup değişkeninin bakış açısı alma üzerinde etkili olduğu $(B=-.48, S E=$ $.23, p=.04)$, bakış açısı almanın ise tutumlar ile anlam11 bir şekilde ilişkili olduğu görülmüştür $(B=.36, S E=$ $.13, p<.01)$. Dolaylı etkilere bakıldığında grubun tutumlar üzerindeki etkisinin bakış açısı alma değişkeni tarafından anlamlı bir şekilde açıklandığı görülmüştür $\left(B=-.17, S E_{\text {boot }}=.13,95 \%\right.$ CI [-.52, -.005]). Yaklaşmac1 davranışları yordayan diğer bir modelde bakış açısı alma yaklaşmacı davranışla olumlu şekilde ilişkili bulunmuştur $(B=.29, S E=.09, p<.01)$. Bakış açısı almanın arac1 etkisi yaklaşmacı davranışlar üzerinde de anlamlı olarak bulunmuştur $\left(B=-.13, S E_{\text {boot }}=.10,95 \%\right.$ CI $[-.44$,
-.007]). Son olarak kaçınmacı davranışların bağımlı değişken olarak eklendiği modelde, bakış açısı alma değişkeni kaçınmacı davranış ile olumsuz olarak ilişkilidir ( $B$ $=-.39, S E=.24, p=.04)$. Bakış açısı almanın bu ilişkide de anlamlı bir aracı değişken olduğu görülmüştür ( $B=$ $.09, S E_{\text {boot }}=.08,95 \%$ CI $\left.[.003, .33]\right)$. Şekil 1 değişkenler için aracı testi katsayılarını göstermektedir.

\section{Tartışma}

Birinci çalışmanın sonuçları, Kıbrıslı Türk ve Rumlar bağlamında içgrup kimliğiyle özdeşleşmenin, sosyal kimlik kuramına uygun olarak ve öne sürdüğümüz Hipotez 1'i destekleyerek (Hipotez 2'nin aksine), dışgrup bakış açısı almayı azalttığı, bunun da dolaylı olarak dışgruba yönelik tutum ve davranışsal eğilimleri olumsuz etkilediğini göstermiştir. Bu bulgular literatürde daha önceki çalışmalarla uyumludur; içgrupla özdeşleşme korelasyonel çalışmalarda etnosentrizm ile olumlu ilişkili bulunmuştur (Perreault ve Bourhis, 1999). Bunun yanında, içgrup kimliğiyle özdeşleşmenin tutum ve yaklaşma davranıșsal eğilimi üzerindeki doğrudan etkisi istatistiki olarak anlamsız olmasına rağmen, kaçınmacı eğilimler üzerindeki etkisi anlamlıdır. Ayrıca, içgrup kimliğiyle özdeşleşme dışgrubun bakış açısını almayı daha olumsuz hale getirerek dolaylı şekilde dışgrup tutumlarını daha olumsuz hale getirmiş, yaklaşmacı tutumları azaltıp, kaçınmacı tutumları arttırmıştır. Bulguların genellenebilirliğini ve farklı gruplararası bir bağlamda benzer sonuçlar doğurup doğurmadığını incelemek amacryla birinci çalışma ile eş zamanlı olarak ikinci bir çalışma yapılmıştır. 


\section{İkinci Çalıșma}

İkinci çalışmada Türkiyeli Türk katılımcıların Suriyeli göçmenlere yönelik tutum ve davranışsal eğilimlerinin öngörülmesi planlanmıştır. Türkiye, yıllardır birçok farklı dini, etnik ve siyasal grubun birlikte yaşadığı bir toplum olmuştur. Bu bağlamda Türkiye'de son yıllarda yaşanan gruplararası süreçlerden biri de Türkiye'ye göç eden Suriyeli göçmenler konusu olmuştur. Yapılan istatistiki araştırmalara göre Türkiye, Suriyeli göçmenleri kabul konusunda birinci sırada yer almakta, son verilere göre yaklaşık 3.5 milyon Suriyeli göçmen barındırmaktadır. Bu göçmenlerin, önemli bir kısmı okul çağında yer almaktadır. T.C. İçişleri Bakanlığı, Göç İdaresi Genel Müdürlügüu verilerine göre, 2018 yıll itibariyle Türkiye'de geçici koruma statüsündeki Suriyeli Mülteci sayısının toplam 3.531.416 olduğu ifade edilmektedir. Suriyeli göçmenlerin, okul yaşında bulunan çocuklarının sayısının ise 1.128.126 olduğu belirtilmektedir (Göç İdaresi Genel Müdürlüğü, 2018). Bu alanda yapılan çalışmalar önümüzdeki 10 yıl içerisinde bu sayının artmaya devam edeceğini (Tunç, 2015), Türkiye'nin artık 'göç veren' bir ülkeden ziyade 'göç alan' bir ülke haline geldiğini göstermektedir (Ünal, 2014). Bu da Türkiye'de toplumsal barış ve anlayışın arttırılabilmesi ve Suriyeli göçmenlerin Türkiye'ye başarılı bir şekilde kaynaştırılmasını sağlamak için bu grup üyelerine yönelik tutum ve davranışsal eğilimlerin belirlenmesi adına yapılacak çalışmaların önemini belirtmektedir.

Suriyeliler ile ilgili son yıllarda yürütülen çalışmalar, Türklerin Suriyeli göçmenlere yardım konusunda olumlu olduğunu, dolayısıyla bu gruba karşı sempati duyduğunu, ancak toplumun büyük bir kısmının Suriyelilerin Türkiye'ye kabul edilmemesi ve vatandaşlık verilmemesi gibi katı görüşlere sahip olduğunu göstermektedir (Bagci, Piyale, Bircek ve Ebcim, 2017; Erdogan, 2014). Bunun yanında Türklerin büyük bir kısmının Türkiye'ye gelen göçü bir firsattan ziyade bir sorun olarak algıladıkları (\%54), büyük bir çoğunluğun bu grubu bir 'tehdit' unsuru olarak değerlendirdiği (\%70) ve birçok haberde bu grubun dışlayıcı ve küçümseyici söylemlerle nitelendirildiği belirtilmiştir (Ünal, 2014).

Yıllardan beri birçok farklı kültüre ev sahipliği yapan Türkiye'de Türk kimliği önemli bir nitelik taşımaktadır. Taşdemir'in (2018) Suriyelilere yönelik sosyal mesafe, içgrup yanlılığı, ve tehdit algılarını ulusal kimlikler 1şığında incelediği çalışmada, ulusal katılımın (örneğin "Türk kimliğine sahip olabilmek için vatana ve millete karş1 sorumluluk sahibi olmak gereklidir") tehdit alg1sını arttırdığı, bunun da içgrup yanlılığı ile ilgili olumlu ve sosyal mesafe ile ise olumsuz bir şekilde ilişsili ol- duğu bulunmuştur. Ulusal özcülüğün ise (örneğin "Türk kimliğine sahip olabilmek için Türk aileden gelmiş olmak gereklidir"), yalnızca sosyal mesafe ile ilişkili olduğu görülmüş̧ür. Başka bir çalışmada Bagci ve Birinci (2017) ulusal kimliğin Suriyelilere yönelik örtük ve açık önyargılarla olumlu yönde ilişsili olduğunu, bu ilişskilerin diğer grubun bakış açısını almanın azalması yoluyla açıklandığını göstermiştir. Tüm bu bulgulara dayanarak, Türk kimliğiyle özdeşleşmenin katılımcılar arasında Suriyelilerin bakış açısını almayı azaltacağı ve bu gruba dair algilanan tehdidi arttrracağ Suriyelilere yönelik tutumlar ve davranıșsal eğilimleri daha olumsuz hale getireceği öne sürülebilir (Hipotez 1).

\section{Yöntem}

\section{Örneklem ve İșlem}

Çalışmaya toplam 319 kişi katılmıştır (205 kadın, 113 erkek, 1 diğer, Ort. ${ }_{\text {vas }}=26.61, S S=9.48$, Ranj $=$ 16-91). Demografik formda katılımciların sosyo-ekonomik düzeyi iki madde ile belirlenmiştir. Katılımcılar ilk olarak öznel sosyo-ekonomik düzey sorusunu cevaplamıştır ("Sosyo-ekonomik durumunuzu nasıl değerlendiriyorsunuz?", 1 = oldukça düşük, 4 = oldukça yüksek, Ort. $=2.12, S S=.56$ ). Eğitim seviyesi ise en son mezun olunan okul düzeyi ile ölçülmüştür (\%2.8 ilkokul mezunu, \%3.1 ortaokul mezunu, \%59.2 lise mezunu, \%30.4 üniversite mezunu, \%4.1 yüksek lisans/doktora mezunu, $\% .3$ diğer). Katılımcıların etnik kökeni ankette asıl soruların ardından sorulmuş, tek bir maddeyle ölçülmüştür (“Kendinizi ait ettiğiniz etnik grup nedir?"; \%80.3 Türk, $\% 1.9$ Kürt, \%1.9 Boşnak, \%1.3 Çerkes, \%10.7 Diğer, ve $\% 4.1$ Bilinmeyen). ${ }^{2}$

Katılımcılar araştırmaya gönüllü araştırma asistanları tarafından davet edilmiş, çeşitli şehirlerden (İstanbul, Ankara, İzmir, Bursa gibi) çevrimiçi anketleri doldurmuşlardır (Temmuz 2018). Çevrimiçi anketler sosyal medya platformları (Facebook, Twitter ve Messenger gibi) üzerinden ve elektronik posta yöntemiyle dağıtılmıştır. Katılımcılar araştırmada öncelikle demografik formu doldurmuşlar, daha sonra deneysel prosedüre katılmışlardır. Katılımcılar iki gruba (kontrol grubu $n$ $=166$, deneysel grup $n=153$ ) rastgele atanmıştır. Hem kontrol hem deneysel grupta birinci çalışmada kullanılan işlemin aynısı uygulanmıştır (Birinci çalışmanın yöntem bölümüne bakınız). Kontrol grubunda katılımc1lardan son yaptıkları tatili hatılamaları ve bununla ilgili detayları yazmaları beklenirken, özdeşleșme grubunda katılımcıların Türkler ile ilgili kendilerini gururlandıran ve mutlu eden bir anıyı hatırlamaları istenmiştir (Sassenberg ve Wieber, 2005).

2 Etnik köken bölümündeki kategoriler arasında ‘Suriyeli’ kategorisi de yer almış, katılımcılar arasında bu gruba ait olduğunu belirten katılımcı gözlenmemiştir. 


\section{Manipülasyon kontrolü}

Manipülasyon kontrolü birinci çalışmadaki gibi iki madde ile belirtilmiştir ("Türklere bağlılık duyarım" ve "Türk olduğumu hissederim"). Kullanılan iki maddenin oluşturduğu ölçeğin güvenirliği yüksek bulunmuştur $(r=$ $.86, p<.001)$. Uygulanan bağımsız iki örneklem t-testi sonuçlarına göre, kontrol grup (Ort. $=5.04, S S=2.21)$ ile özdeşleşme grubu (Ort. $=5.49, S S=1.88)$ arasında anlamlı bir şekilde fark olduğu, özdeşleşme grubundaki katılımcıların kontrol grubundakilere göre Türk kimlikleri ile daha yüksek seviyede özdeşleştikleri bulgulanmıştır, $t(315.10)=-1.99, p=.047$.

\section{Veri Toplama Araçları}

Kontrol değişkenleri. Araştırmamızda yaş, öznel sosyo-ekonomik seviye ve etnik grup $(0=$ Diğer, $1=$ Türk) demografik değişkenleri kontrol değişkenleri olarak analizlere dahil edilmiştir. Bunun yanında anketin sonunda katılımcıların Suriyeliler ile tanışıklık düzeyi ölçülmüştür ("Genel olarak günlük hayatınızda Suriyelilerle ne derece temas kuruyorsunuz?”; $1=$ hiç, 7 = çok sık, Ort. $=2.07, S S=1.56$, Çalışma 1). Suriyeliler ile günlük temas seviyesinin de Suriyelilere yönelik tutumlar ve davranışsal eğilimleri güçlü bir şekilde yordayabileceği düşünülerek (Çalışma 1), bu değişken de kontrol değișkeni olarak analizlere eklenmiștir.

Ana değişkenler için kullanılan ölçeklerde aksi belirtilmediği sürece cevap seçenekleri 1 (kesinlikle katılmıyorum) ile 7 (kesinlikle katıllyorum) arasinda Likert tipi cevap ölçeği kullanılarak belirtilmiştir.

Dışgrubun bakış açısını alma. Dışgrubun bakış açısını alma ölçeği katılımcıların kendilerini ne derece Suriyelilerin yerine koyabildiklerini ve onların bakış açılarını alabildiklerini ölçmektedir (Aberson ve Haag, 2007; Çalışma 1, "Suriyelileri düşündüğümde olaylara onların bakış açısından bakabiliyorum" ve "Suriyelilerin dünya görüşlerini anlayabiliyorum"). Bu iki maddenin Türkçe'ye çevrilmiş hali daha önce Türk-Suriyeli gruplararası bağlamda yürütülmüş bir çalışmada kullanılmıştır (Bagci ve Birinci, 2017). Ölçeğin güvenilirliği uygun bulunmuştur $(r=.54, p<.001)$.

Algılanan tehdit. Suriyelilere yönelik algılanan tehdit yedi maddelik iki uçlu bir ölçekle ölçülmüş, katılımcıların Suriyelileri farklı konularda ne derece tehdit edici-zenginleştirici buldukları belirtilmiştir (Florack ve ark., 2003, çalışma 1). Ölçek maddeleri hem gerçekçi tehdit, hem de sembolik tehdit içermiştir ("Suriyelileri din/dil/politik görüş/kültürel değerler/işsizlik/ekonomi konusunda ne derece tehdit edici/zenginleştirici buluyorsunuz?" 1 = tehdit edici, 7 = zenginleştirici). Ölçeğin maddeleri hem sembolik hem de gerçekçi tehdit içerdiğinden yapılan doğrulayıcı faktör analizi sonuçlarında ölçek maddelerinin iki faktöre beklenildiği şekilde yük- lendiği; işsizlik ve ekonomi unsurlarının birinci faktörde (gerçekçi tehdit algısı, total varyans $=15.22$ ), diğer unsurların ise ikinci faktörde (sembolik tehdit algıs1, total varyans $=60.41$ ) yüklendiği görülmüştür. Ölçeklerin güvenilirlik değerleri her iki ölçek için de uygundur (Gerçekçi tehdit algısı için, $r=.72, p<.001$; Sembolik tehdit algısı için, Cronbach alfa $=.84$ ).

Dışgruba yönelik tutumlar. Suriyelilere yönelik tutumları ölçmek amacıyla tek maddelik duygu termometresi kullanılmıştır (Esses ve ark., 1993, Çalışma 1). Katılımcılar Suriyelilere yönelik hissettikleri sıcaklık seviyesini açık uçlu olarak 0 (maksimum olumsuz) ile 100 (maksimum olumlu) derece arasında belirtmiştir.

Dişgruba yönelik davranışsal eğilimler. $\mathrm{Bu}$ çalışmada Suriyelilere yönelik yaklaşma ve kaçınma davranışları birer madde ile ölçülmüştür. Yaklaşma eğilimi için "Eğer seçme şansınız olsaydı Suriyelilerle ne derece daha fazla temas kurmak isterdiniz," kaçınma eğilimi için ise "Suriyelilerle temas kurmaktan ne derece kaçındığınızı düşünüyorsunuz?" maddeleri kullanılmıştır (Mackie ve ark., 2000). İki madde arasında olumsuz, ancak orta seviyede bir korelasyonel ilişki $(r=-.38, p$ $<$.001) bulunduğundan iki madde ayrı ayrı değerlendirilmiştir.

\section{Bulgular}

\section{Grup farklılıkları}

İlk olarak iki grup arasındaki (kontrol-özdeşleşme) ortalama farklarına bakmak amacıyla yaş, SES, etnik grup ve temas seviyelerinin kontrol değişkeni olarak kullanıldığ1 ve sembolik ve gerçekçi tehdit, dışgrubun bakış açısını alma, tutumlar ile yaklaşmacı ve kaçınmacı davranışsal eğilimlerin bağımlı değişkenler olarak ele alındığı MANCOVA (Multivariate Analysis of Covariance) testi uygulanmıştır. Bulgular, kontrol değişkenlerinden yanlızca temasın çoklu bir etkisinin olduğunu göstermiştir, $F(6,292)=11.17, p<.001, \eta_{p}^{2}=.19$. Grubun çoklu etkisi anlamsızdır, $F(6,292)=1.55, p=.16, \eta^{2} p=.03$. Ancak tekli etkilere bakıldığında grubun gerçekçi tehdit algısı üzerinde etkisi olduğu görülmektedir, $F(1,297)=$ $4.91, p=.028, \eta^{2} p=.02$. Buna göre, özdeşleşmenin artt1rıldığı deneysel grupta algılanan gerçekçi tehdit algısının $($ Ort. $=5.92, S S=.11)$ kontrol grubuna $($ Ort. $=6.25, S S=$ .10) göre daha düşük seviyede belirtildiği bulgulanmıştır. Diğer bağımlı değişkenlerde iki grup arasında anlam11 farklar bulunmamıştır. Tablo 2 iki grup için düzeltilmiş ortalama ve standart hataları göstermektedir.

\section{Aracı değişken analizi}

Ön analizlerde grubun bakış açısını alma değişkeni üzerinde anlamlı bir etkisi olmadığından bu değişken aracı olarak modele eklenmemiş, yalnızca algılanan ger- 
Tablo 2. Kontrol ve Özdeşleşme Grubu için MANCOVA Modeli

\begin{tabular}{lcccc}
\hline & Kontrol grubu & Özdeşleşme grubu & $F$ & $p$ \\
\hline Dişgrubun bakış açısını alma & $3.43(.12)$ & $3.43(.13)$ & .001 & .98 \\
Algılanan gerçekçi tehdit & $6.25(.10)$ & $5.92(.11)$ & 4.91 & .03 \\
Algılanan sembolik tehdit & $5.38(.10)$ & $5.38(.10)$ & .001 & .97 \\
Dışgruba yönelik tutumlar & $30.00(1.93)$ & $28.23(2.01)$ & .40 & .53 \\
Dışgruba yönelik yaklaşma eğilimi & $2.21(.12)$ & $2.26(.12)$ & .08 & .77 \\
Dişgruba yönelik kaçınma eğilimi & $4.03(.18)$ & $4.11(.19)$ & .10 & .75 \\
\hline
\end{tabular}

Not. Düzeltilmiş ortalama değerleri ile standart hata değerleri (parantez içinde) belirtilmiştir.

çekçi tehdit değişkeni aracı olarak incelenmiştir. Grup değişkeninin tutumlar ve davranışsal eğilimler üzerindeki etkisine bakmak amacıyla, yaş, SES, etnik grup ve temas kontrol değişkenleri, grup değişkeni bağımsız değişken, gerçekçi tehdit aracı değişken ve tutumlar ile yaklaşmacı ve kaçınmacı davranışlar bağımlı değişken olarak ele alınarak PROCESS Makrosu (Hayes, 2013, Model 4) kullanılmıştır.

Suriyelilere yönelik tutumların bağımlı değişken olarak test edildiği ilk modelde, grup değişkeninin gerçekçi tehdit üzerinde etkili olduğu $(B=-.33, S E=.15$, $p=.028)$, gerçekçi tehdidin ise tutumlar ile anlamlı ve olumsuz bir şekilde ilişkili olduğu görülmüştür $(B=$ $-6.59, S E=1.03, p<.001)$. Dolaylı etkilere bakıldığında grubun tutumlar üzerindeki etkisinin tehdit değişkeni tarafından anlamlı bir şekilde açıklandığı görülmüştür ( $B$ $=2.15, S E_{\text {boot }}=1.00,95 \%$ CI $\left.[.33,4.27]\right)$. Yaklaşmacı davranışları yordayan diğer bir modelde gerçekçi tehdit algısı yaklaşmacı davranışla olumsuz şekilde ilişkili bulunmuştur $(B=-.29, S E=.06, p<.001)$. Tehdidin arac1 etkisi yaklaşmacı davranışlar üzerinde de anlamlı olarak bulunmuştur ( $\left.B=.10, S E_{\text {boot }}=.05,95 \% \mathrm{CI}[.01, .19]\right)$. Son olarak kaçınmacı davranışların bağımlı değişken olarak eklendiği modelde, gerçekçi tehdit algısı kaçınmacı davranış ile olumlu olarak ilişkilidir $(B=.56, S E$ $=.10, p<.001)$. Gerçekçi tehdit algısı bu ilişkide de anlamlı bir aracı değişken olarak görülmüştür $(B=-.18$, $S E_{\text {boot }}=.09,95 \%$ CI [-.37, -.03]). Arac1 model Şekil 2'de sunulmaktadır.

\section{Tartışma}

İkinci çalıșmanın sonuçları Türk kimlikleriyle özdeşleşmenin arttırıldığı deneysel düzenekte katılımcıla-

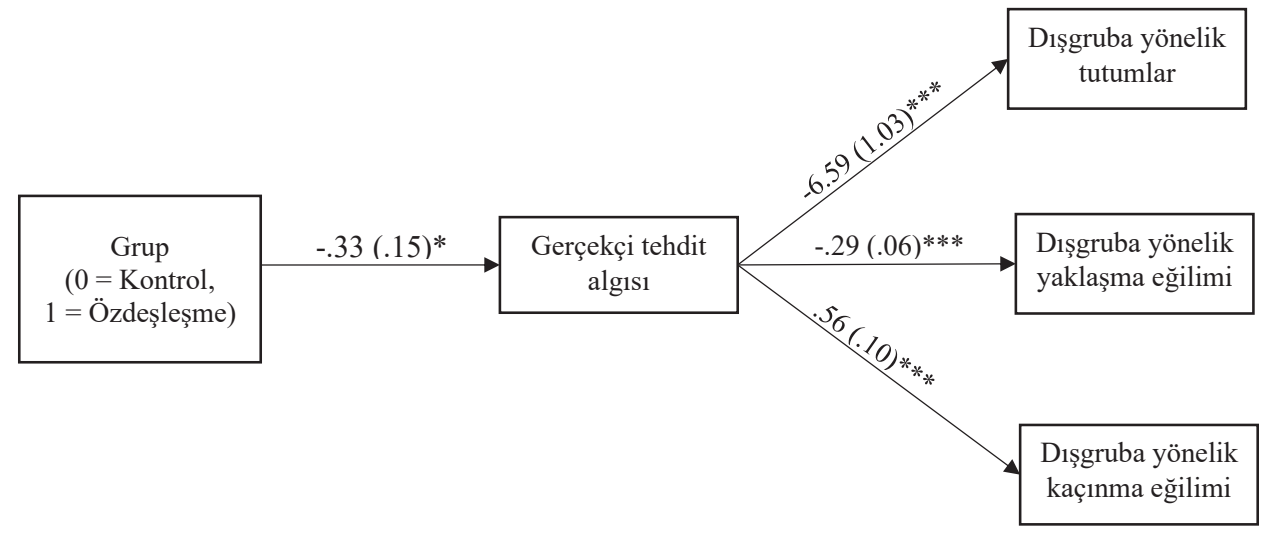

Not. $* * * p<.001, * p<.01$. Standartlaştırılmamış katsayılar ve standart hata değerleri (parantez içinde) belirtilmektedir. Doğrudan etkiler istatistiki olarak anlamsız olduğundan şekil üzerinde gösterilmemiştir.

Şekil 2. İkinci Çalışmada Grubun Tutumlar ve Davranışsal Eğilimler Üzerindeki Dolaylı Etkileri 
rın Suriyelilere yönelik gerçekçi tehdit algısının azald1ğını göstermiştir. Özdeşleşmenin tutumlar ve davranışsal eğilimler üzerinde doğrudan bir etkisi olmasa da, bu etki tehdit aracılığı ile dolaylı şekilde gerçekleşmektedir; buna göre özdeşleşmenin gerçekçi tehdit algısını azaltma yoluyla olumlu tutum ve yaklaşmacı davranışları arttırdığı, kaçınmacı davranışları ise azalttığı gözlenmiştir.

\section{Genel Tartışma}

$\mathrm{Bu}$ araştırmanın amacı içgrup kimlikleriyle özdeşleşmenin dışgruba yönelik tutum ve davranışsal eğilimler üzerindeki etkisini iki farklı gruplararası bağlamda incelemektir. Araştırmamız deneysel bir araştırma deseni kullanılması ile özdeşleşmenin etkilerini nedensellik çerçevesinde incelemiştir. Bunun yanında iki farklı değişkenin - dişgrubun bakış açısını alma ve algılanan tehdit - bu etkilerdeki arac1 rollerine bakılarak tutum ve davranışların dolaylı şekilde nasıl etkilendiği incelenmiştir. Ayrıca çalışmamız Kıbrıslı Türkler-Rumlar ile Türkiyeli Türkler-Suriyeliler gruplararası ilişkilerini ele alarak içgrup kimliğiyle özdeşleşmenin etkilerini iki farklı sosyo-kültürel çevrede göstermiştir.

Birinci çalışma, araştırmanın birinci hipotezini doğrular nitelikte, Kıbrıslı Türklerin içgrup kimlikleriyle özdeşleşmesinin Kıbrıslı Rumların bakışaçısını almayı azalttığını ve dolaylı olarak Rumlara yönelik tutum ve davranışsal eğilimleri olumsuz etkilediğini göstermiştir. Bu bulgular, Sosyal Kimlik Kuramının (Tajfel ve Turner, 1979) da önerdiği gibi kişilerde içgrup kimliğin baskın hale gelip güçlenmesiyle dışgruba bakışaçısını alabilme özelliğinin azaldığını göstermektedir. Alanyazındaki diğer çalışmalar da daha önce içgruplarıyla yüksek seviyede özdeşleşen kişilerin daha etno-merkezci olduklarını ve sonucunda da dışgruplara daha ayrımcı yaklaştıkların1 göstermiştir (örn. Perreault ve Bourhis, 1999). Benzer bulgular diğer çatışmalı grup ilişkileri yaşanan ülkelerde de gözlemlenmiştir (örn. Güney Afrika, Duckitt ve Mphuthing, 1998; Kuzey İrlanda, Noor, Brown ve Prentice, 2008).

Türkiye'deki Suriyeli göçmenlere yönelik tutum ve davranışların söz konusu olduğu ikinci çalışmada ise, birinci çalışmanın ve birinci hipotezin aksine, Türklerin ulusal kimlikleriyle özdeşleşmesi sonucunda Suriyelilere yönelik daha az tehdit hissettikleri, bunun sonucunda da özdeşleşmenin dolaylı olarak dışgruplara yönelik tutum ve davranışları daha olumlu hale getirdiği görülmektedir. Bu bulgu Phinney ve arkadaşlarının (2007) önerdiği gibi kişilerin özdeşleşmeleri arttıkça kimliklerine daha güvenli bir şekilde bağlandıklarını ve daha az tehdit hissettiklerini, bunun da dolaylı olarak dışgruplara yönelik tutum ve davranışları daha olumlu hale getirdiğini göstermektedir.
Bu iki çalışmanın zıt sonuçları birkaç farklı mekanizmayla açıklanabilir. Birincisi, Kıbrıstaki Türk-Rum gruplararası bağlamı uzun zaman boyunca çatışma algısının yüksek şekilde hissedildiği bir gruplararası ortam olarak karşımıza çıkmaktadır. Buna göre Kıbrıs'ta uygulanmış çalışmalar iki grup arasında yaşanmış çatışma ve anlaşmazlıkların halen hissedildiğini göstermektedir (örn. MacGinty, 2010). Türk-Suriyeli bağlamı ise, son on yılda belirgin hale gelmiş, gruplararası çatışmanın daha az hissedilir olduğu gruplararası bir ortam oluşturmaktadır. Bunun yanında Kıbrıslı Rumlar ve Türkler halen oldukça ayrık (segregated) yaşamaya devam ederken, Türklerin Suriyelilerle teması son yıllarda artmıştır. İkinci faktör olarak Kıbrıslı Rumların ve Suriyelilerin statü olarak bulundukları toplumda farklı şekillerde yaşıyor olmaları düşünülebilir. Kıbrıs ortamında iki grubun statü olarak (sayı ve güç) birbirinden daha az farklı olduğu ve Kıbrıslı Türklerin Kıbrıs'ta daha kalıcı bir konuma sahip oldukları görülürken, Türkiye'de Suriyeliler sayıca azınlık ve 'göçmen' konumunda, Türkler ise 'ev sahibi' konumundadır. Bu da içgrup kimlikleriyle özdeşleşmenin her iki kültür ve grup arasında farklı sonuçlar doğurabileceğine dikkat çekmektedir. Ayrıca, iki grup için algılanan 'Türk' kimlikleri seviyesi birbirinden farklı gözükmektedir. Hem kontrol gruplarında, hem de özdeşleşme grubunda manipülasyon sonrası Türk kimlikleriyle özdeşleşme Türkiye ortamında Kıbrıs ortamına göre daha yüksektir. Bu da iki grupta uygulanan deneysel prosedürün farklı sonuçlar üretmesine sebep olmuş olabilir.

Bunun yanında her iki grup için de farklı gruplararası süreçlerin aracı değişken olarak rol oynaması tartışmaya değer bir konudur. Kıbrıs bağlamında dışgrubun bakış açısını alma aracı değişken olarak çalışırken, Türkiye bağlamında algılanan gerçekçi tehdit algısının özdeşleşmenin tutumlar ve davranışsal eğilimler üzerindeki etkisini açıkladığı görülmektedir. Kıbrıs bağlamında özellikle dişgrubun bakış açısını alma değişkeninin gruplararası tutumları açıklamadaki etkisi daha önceki çalışmalarda bulgulanmıştır. Örneğin, Husnu ve Crisp (2015) kurgusal temas sonucunda Kibrislı Türklerin Kıbrıslı Rumlara yönelik olumlu değerlendirmelerinin dışgrup bakış açısını alma aracılığıyla gerçekleştiğini göstermiştir. Buna göre, Kıbrıs’ta iki grubun ayrı yaşamaları da değerlendirildiğinde bu bağlamda tehdit alg1sından ziyade dışgrubu anlama ve kendini karşı grubun yerine koyabilme özelliğinin özdeşleşmenin etkilerinde daha belirleyici rolü olduğu öne sürülebilir. Türkiye'de ise son on yılda artan Suriyeli göçmen sayısı ile, Türklerin Suriyelilere yardım konusunda olumlu olduğu ve bu gruba empati duyduğu, ancak özellikle işsizlik ve vatandaşlık gibi gerçekçi tehdit unsurları ele alındığında bu gruba dair tehdit algılarının yüksek olduğunu göstermiştir (örn. Bagci ve ark., 2018; Erdoğan, 2014; Ünal, 
2014). Bu bağlamda Türklerin Türklükleri ile olumlu duygular hissetmeleri, katılımcılarda bu yüksek gerçekçi tehdit algısının ve savunma mekanizmasının zayıflamasını ve böylece dişgruba yönelik tutum ve davranışsal eğilimlerin daha olumlu olmasını sağlamış olabilir. Böylece, Türklerin Suriyelilere yönelik algılarında bu grubun bakış açısını almaktan ziyade algılanan gerçekçi tehdit kavramının tutum ve davranışlarda daha açıklayıcı bir fonksiyonu olduğu düşünülebilir.

Bunun yanında araştırmamızın bulguları Türkiye'deki diğer bazı çalışmalarla zıt sonuçlar doğurmuştur (örn. Bagci ve Birinci, 2017; Taşdemir, 2018). Bunun sebepleri arasında daha önceki araştırmaların yalnızca korelasyonel yöntemler kullanması, bu çalışmada ise deneysel bir prosedür kullanılmış olması sayılabilir. Ayrıca, araștırmamızda kullanılan manipülasyonda Türk kimliği ile özdeşleşmenin yalnızca olumlu yönü ön plana çıkarılmıştır. Daha önceki çalışmalar sosyal kimliklerin çeşitli insani ihtiyaçları (aidiyet, öz-yeterlik, benlik sayg1s1 gibi) sağladığı takdirde bireylere faydalı olduğunu, sağlamadığında ise 'sosyal lanet' (social curse) olabileceklerini öne sürmüștür (örn. Haslam, Jetten ve Haslam, 2012). Buna göre çalışmamızdaki deneysel prosedür olumlu bir kimlik algısı sağlayarak katılımcıların aidiyet ve benlik saygısı gibi algılarını yükseltmiş, bunun verdiği güven ile diğer gruplara daha olumlu ve toleranslı yaklaşılmasını sağlamış olabilir. İleriki araştırmalar Türk kimliği ile özdeşleşmenin ardındaki güdüsel faktörleri de araştırma sorularına ekleyerek içgrup kimliğiyle özdeşleşmenin dişgruplara yönlik tutumlardaki etkisini daha kapsamlı bir şekilde incelemelidir.

Özet olarak bu çalışma, hem kuramsal hem de uygulamalı anlamda ulusal ve uluslararası literatüre katk1 sağlamaktadır. Öncelikle, içgrupla özdeşleşmenin iki olası etkisi (olumlu veya olumsuz tutum ve davranışsal eğilimler) iki farklı gruplararası bağlamda test edilmiştir. Daha önceki çalışmalar içgrupla özdeşleşmenin birçok farklı gruplararası süreci yordadığını ve/veya düzenlediğini, bu etkilerin kimi zaman olumlu kimi zaman olumsuz olabildiğini göstermiştir (Brewer, 2001), ancak bu etkileri farklı kültürler ve gruplar arasında test eden çalışmalar oldukça az sayıdadır. Bu çalışma da diğer birçok gruplararası süreçte gözlemlendiği gibi, içgrupla özdeşleşmenin etkilerinin sosyo-kültürel bağlama göre değişebileceğini göstermektedir. Bunun yanında içgrupla özdeşleşme nadiren deneysel bir prosedür kullanılarak test edilmiş (örn. Sassenberg ve Wieber, 2005), çalışmaların çoğu korelasyonel yöntemlere dayanarak, içgrupla özdeşleşme ile tutumlar arasındaki ilişkileri nedensellik çerçevesinde incelememiştir.

Çalışmamız Kıbrıs konusu ve Türk-Suriyeli gruplar arasındaki uzlaşmanın sağlanması açısından tasarlanacak uygulamalı programların geliştirilmesini sağ- layabilir. Her iki bağlamda olumsuz grup süreçlerini azaltmak ve uzlaşmaya gidebilmek için içgrupla özdeşleşmeyi sınırlarıyla içeren (örneğin Kıbrıs bağlamında içgrup özdeşleşmesini azaltarak, Türk-Suriyeli bağlamında arttırarak) dışgrubun bakış açısını alma ve tehdit algısının düşürülmesiyle çeşitli müdahale programları tasarlanabilir. Örneğin Kıbrıs’ta Kıbrıslı Türk içgrup özdeşleşmesi yerine 'Kıbrıslılık' üst kimliğini kullanarak gruplararası doğrudan ve dolaylı temas çalışmaları gerçekleştirilebilir. Daha önceki çalışmalar temasın bireylerde etno-merkezci yaklaşımı azalttığını, kişileri içgruba yönelimden uzaklaştırarak bilişsel olarak özgürleştirdiğinden bahsetmektedir (Bagci, Piyale, Sen ve Yildirim, 2019; Hodson, Crisp, Meleady ve Earle, 2018). Türk bağlamında ise içgrup kimliğiyle başarılı ve güvenli bir şekilde özdeşleşmenin arttırılması için yapılacak uygulamalı çalışmalar Suriyelilere yönelik tutum ve davranışların iyileştirilmesinde önemli rol oynayabilir.

Çalışmamızın literatüre katkılarının yanında çeşitli sınırlılıkları bulunmaktadır. İlk olarak çalışmamızın bulguları değerlendirildiğinde, anlamlı etkilerdeki etki büyüklükleri düşüktür, bu da anlamlı bulgular elde etmemize rağmen sonuçların dikkatli şekilde değerlendirilmesi gerektiğini göstermektedir. İleriki araştırmalar daha güçlü özdeşleşme manipülasyonları ile (örneğin görsel ve duyusal manipülasyonlar) daha güçlü bulgular elde edebilir. Bunun yanında çalışmamızda yalnızca iki değişken aracı olarak test edilmiştir. Gruplararası ilişkiler alanyazınında içgrup kimliğiyle özdeşleşme ile dışgruba yönelik tutum ve davranışsal eğilimler arasındaki ilişkiyi açıklayan diğer mekanizmalar (örn. çatışma algısı, gruplararası kayg1) deneysel yöntemler kullanılarak test edilmelidir. Çalışmamızda iki farklı sosyo-kültürel bağlamın kullanılmış olması araştırmamızın güçlü bir yönü olsa da her iki gruplararası ortam, algılanan tehdit ve çatışma, grupların statüleri ve sosyo-kültürel çevre bakımından oldukça farklıdır. İleriki çalışmalar aynı sosyo-kültürel ortamda farklı gruplararası ilişkileri inceleyebilir. Örneğin, Türkiye'de benzer bir çalışma etnik kimlikler üzerinden Türk-Kürt gruplararası bağlamında incelenebilir ya da farklı sosyo-kültürel ortamlardan alınmış benzer şekilde çatışma yaşanan iki gruplararası bağlam Kıbrıslı Türk-Rum ve Türkiyeli Türk-Kürt ilişkileri ileriki çalışmalarda karşılaştırılabilir.

Bunun yanında, ikinci çalışmada 'Türk kimliği' ile özdeşleşme manipüle edilmiş, ancak bu kimliğin Türk ulusal kimliğini belirttiği katılımcılara açıkça yansıtılmamıştır. Çalışmamızda hayal edilen senaryolara yakından bakıldığında katılımcıların çoğunlukla Türk ulusal kimliği ile ilgili hayal kurdukları görülmektedir, ancak etnik kimliği Türk olmayıp ulusal kimliği Türk olan bazı katılımcılar için Türk kimliklerle özdeşleşme seviyesi daha düşük seviyede yaşanmış ya da ortak bir üst kimlik 
olarak algılanmış olabilir (örn. Çelebi, Verkuyten, Köse ve Maliepaard, 2014). İleriki çalışmalarda benzer senaryolar kimliklerin daha açık tanımları belirtilerek uygulanabilir.

Sonuç olarak bu araştırmada içgrupla özdeşleşmenin dişgruplara yönelik tutum ve davranışsal eğilimler üzerindeki etkisi iki farklı gruplararası bağlamda iki karşıt bulgu göstermiştir. Kıbrıslı Türkler arasında Türk kimliği ile özdeşleşmenin Rumların bakış açısını almayı azaltarak bu gruba dair tutum ve davranışsal eğilimleri olumsuz etkilediği görülürken, Türkiye'de yaşayan Türklerin Türk kimlikleriyle özdeşleşmelerinin Suriyelilere yönelik gerçekçi tehdit algısını azalttığı ve sonucunda bu gruba yönelik tutum ve davranışsal eğilimleri olumlu yönde etkilediği bulgulanmıştır. İleriki çalışmaların benzer özdeşleşme manipülasyonlarını farklı gruplararası bağlamlarda ve daha çeşitli aracı ve bağımlı değişkenler üzerinde sınamaları önerilmektedir.

\section{Kaynaklar}

Aberson, C. L. ve Gaffney, A. M. (2008). An integrated threat model of explicit and implicit attitudes. European Journal of Social Psychology, 39, 808830.

Aberson, C. L. ve Haag, S. C. (2007). Contact, perspective taking, and anxiety as predictors of stereotype endorsement, explicit attitudes, and implicit attitudes. Group Processes \& Intergroup Relations, 10, 179-201.

Abrams, D., Eller, A. ve Bryant, J. (2006). An age apart: the effects of intergenerational contact and stereotype threat on performance and intergroup bias. Psychology and Aging, 21, 691-702.

Allport, G. W. (1954). The nature of prejudice. Cambridge, MA: Addison-Wesley.

Andrighetto, L., Mari, S., Volpato, C. ve Behluli, B. (2012). Reducing competitive victimhood in Kosovo: The role of extended contact and common ingroup identity. Political Psychology, 33, 513529.

Bagci, S. C. ve Birinci, B. (2017). Religious and national identity levels predicting subtle and blatant prejudice towards Syrian refugees: Empathy and perspective-taking as mediators. Arapgirlioğlu, H., Atik, A., Elliott, R. L. \& Turgeon, E. (Eds.) içinde, Researches on Science and Art in 21st Century Turkey. Istanbul: Gece Kitaplığı.

Bagci, S. C. ve Çelebi, E. (2017a). Etnik ve ulusal kimlikler ile dışgrup tutumları ilișkisinde çatışma alg1s1 ve dişgruba sorumluluk yükleme. Türk Psikoloji Dergisi, 32, 63-74.

Bagci, S. C. ve Çelebi, E. (2017b). Gruplararası temas ve çatışma ile dışgrup tutumlar ve çokkültürlülüğe destek ilişkisinde algılanan tehdit ve gruplararası kaygının aracı rolü. Türk Psikoloji Yazıları, 20, 3-18.

Bagci, S. C., Piyale, Z. E., Bircek, N. I. ve Ebcim, E. (2017). Think beyond contact: Reformulating imagined intergroup contact theory by adding friendship potential. Group Processes \& Intergroup Relations, 21, 1034-1052.

Bagci, S. C., Piyale, Z. E., Sen, E. ve Yildirim, O. (2019). Beyond shifting intergroup attitudes: Intergroup contact's association with socio-cognitive skills and group-based ideologies. Journal of Theoretical Social Psychology, 3, 176-188.

Bagci, S. C., Stathi, S., \& Piyale, Z. E. (2019). When imagining intergroup contact mobilizes collective action: The perspective of disadvantaged and advantaged groups. International Journal of Intercultural Relations, 69, 32-43. 
Bagci, S. C. ve Turnuklu, A. (2019). Intended, unintended, and unknown consequences of contact. Social Psychology, 50, 7-23.

Bar-Tal, D. (2007). Sociopsychological foundations of intractable conflicts. American Behavioral Scientist, 50, 1430-1453.

Bar-Tal, D. (2010). Culture of conflict: Evolvement, institutionalization and consequences. D. Bar-Tal içinde, Personality, human development, and culture: International perspectives on psychological science (Cilt 2, s. 183-198). R. Schwarzer \& P. A. Frensch.

Barlow, F. K., Paolini, S., Pedersen, A., Hornsey, M. J., Radke, H. R., Harwood, J., ... \& Sibley, C. G. (2012). The contact caveat: Negative contact predicts increased prejudice more than positive contact predicts reduced prejudice. Personality and Social Psychology Bulletin, 38, 1629-1643.

Batson, C. D. (1997). Empathy and attitudes: Can feeling for a member of a stigmatized group improve feelings toward the group? Journal of Personality and Social Psychology, 72, 105-118.

Berry, J. W. (1984). Cultural relations in plural societies. N. Miller ve M. Brewer (Eds.) içinde, Groups in contact (s. 11-27). New York: Academic Press.

Bizman, A. ve Yinon, Y. (2001). Intergroup and interpersonal threats as determinants of prejudice: The moderating role of in-group identification. Basic and Applied Social Psychology, 23, 191-196.

Brewer, M. B. (2001). The many faces of social identity: Implications for political psychology. Political Psychology, 22, 115-125.

Brewer, M. B. (1999). The psychology of prejudice: Ingroup love or outgroup hate? Journal of Social Issues, 55, 429-444.

Cehajic, S., Brown, R. ve Castano, E. (2008). Forgive and forget? Antecedents and consequences of intergroup forgiveness in Bosnia and Herzegovina. Political Psychology, 29, 351-367.

Çelebi, E., Verkuyten, M., Köse, T. ve Maliepaard, M. (2014). Out-group trust and conflict understandings: The perspective of Turks and Kurds in Turkey. International Journal of Intercultural Relations, 40, 64-75.

Duckitt, J., ve Mphuthing, T. (1998). Group identification and intergroup attitudes: a longitudinal analysis in South Africa. Journal of Personality and Social Psychology, 74, 80-85.

Erdoğan, M. M. (2014). Türkiye'deki Suriyeliler: Toplumsal kabul ve uyum araştırması [Syrians in Turkey: Social acceptance and adaptation research] (Report). Ankara, Turkey: Hacettepe Üniversitesi Göç ve Siyaset Araştırmaları Merkezi.
Esses, V. M., Haddock, G. ve Zanna, M. P. (1993). Values, stereotypes, and emotions as determinants of intergroup attitudes. Mackie, D., M. ve Hamilton, D., L. (Eds.) içinde, Affect, cognition and stereotyping: Interactive processes in group perception (s. 137-166). San Diego: Academic Press.

Florack, A., Piontkowski, U., Rohmann, A., Balzer, T. ve Perzig, S. (2003). Perceived intergroup threat and attitudes of host community members toward immigrant acculturation. The Journal of Social PSychology, 143, 633-648.

Galinsky, A. D. ve Moskowitz, G. B. (2000). Perspective-taking: Decreasing stereotype expression, stereotype accessibility, and in-group favoritism. Journal of Personality and Social Psychology, 78, 708-724.

González, K. V., Verkuyten, M., Weesie, J. ve Poppe, E. (2008). Prejudice towards Muslims in the Netherlands: Testing integrated threat theory. British Journal of Social Psychology, 47, 667-685.

Göç İdaresi Genel Müdürlüğü (2018). 2016 Göç Raporu. http://www.goc.gov.tr/files/files/2016 yiik goc raporu_haziran.pdf (06.11.2018 tarihinde ulaşıld1)

Hayes, A. F. (2013). Introduction to Mediation, Moderation, and Conditional Process Analysis: A Regression-Based Approach. New York, NY: The Guilford Press.

Herek, G. M., ve Capitanio, J. P. (1996). "Some of my best friends": Intergroup contact, concealable stigma, and heterosexuals' attitudes toward gay men and lesbians. Personality and Social Psychology Bulletin, 22, 412-424.

Hewstone, M. ve Greenland, K. (2000). Intergroup conflict. International Journal of Psychology, 35, 136-144.

Hinkle, S. ve Brown, R. (1990). Intergroup comparisons and social identity: Some links and lacunae. D. Abrams \& M. Hogg (Eds.) içinde, Social identity theory: Construction and critical advances (s. 48-70). London: Harvester Wheatsheaf.

Hodson, G., Crisp, R. J., Meleady, R., ve Earle, M. (2018). Intergroup contact as an agent of cognitive liberalization. Perspectives on Psychological Science, 13, 523-548.

Husnu, S. ve Crisp, R. J. (2010). Imagined intergroup contact: A new technique for encouraging greater inter-ethnic contact in Cyprus. Peace and Conflict: Journal of Peace Psychology, 16, 97-108.

Husnu, S. ve Crisp, R. J. (2015). Perspective-taking mediates the imagined contact effect. International Journal of Intercultural Relations, 44, 29-34.

Husnu, S. ve Lajunen, T. (2015). Predictors of intergroup bias in Turkish Cypriots. International Journal of Intercultural Relations, 44, 63-71. 
Husnu, S., Mertan, B. ve Cicek, O. (2016). Reducing Turkish Cypriot children's prejudice toward Greek Cypriots: Vicarious and extended intergroup contact through storytelling. Group Processes \& Intergroup Relations, 21, 178-192.

Husnu, S. ve Paolini, S. (2019). Positive imagined contact is actively chosen: Exploring determinants and consequences of volitional intergroup imagery in a conflict-ridden setting. Group Processes \& Intergroup Relations, 22, 511-529.

Jackson, J. W. (2002). Intergroup attitudes as a function of different dimensions of group identification and perceived intergroup conflict. Self and Identity, 1, 11-33.

Levin, M. E., Luoma, J. B., Vilardaga, R., Lillis, J., Nobles, R. ve Hayes, S. C. (2016). Examining the role of psychological inflexibility perspective taking and empathic concern in generalized prejudice. Utah, US: Psychology Faculty Publications.

Link, B. G. ve Cullen, F. T. (1986). Contact with the mentally ill and perceptions of how dangerous they are. Journal of Health and Social Behavior, 27, 289-302.

Lyons, P., Kenworthy, J. ve Popan, J. (2010). Ingroup identification and group-level narcissism as predictors of U.S. citizens' attitudes and behavior toward Arab immigrants. Personality and Social Psychology Bulletin, 36, 1267-1280.

MacGinty, R. (2010). No war, no peace: Why so many peace processes fail to deliver peace. International Politics, 47, 145-162.

Maras, P., ve Brown, R. (2000). Effects of different forms of school contact on children's attitudes toward disabled and non-disabled peers. British Journal of Educational Psychology, 70, 337-351.

Mackie, D., Devos, T. ve Smith, E. R. (2000). Intergroup emotions: Explaining offensive action tendencies in an intergroup context. Journal of Personality and Social Psychology, 79, 602-616.

Masson, C. N. ve Verkuyten, M. (1993). Prejudice, ethnic identity, contact and ethnic group preferences among Dutch young adolescents. Journal of Applied Social Psychology, 23, 156-168.

Mummendey, A., Klink, A. ve Brown, R. (2001). Nationalism and patriotism: national identification and out-group rejection. British Journal of Social Psychology, 40, 159-172.

Noor, M., James Brown, R. ve Prentice, G. (2008). Precursors and mediators of intergroup reconciliation in Northern Ireland: A new model. British Journal of Social Psychology, 47, 481-495.

Pehrson, S., Gonzalez, R. ve Brown, R. (2011). Indigenous rights in Chile: National identity and majority group. Political Psychology, 32, 667-690.
Perreault, S. ve Bourhis, R. Y. (1999). Ethnocentrism, social identification, and discrimination. Personality and Social Psychology Bulletin, 25, 92-103.

Pettigrew, T. F. (1997). Generalized intergroup contact effects on prejudice. Personality and Social Psychology Bulletin, 23, 173-185.

Pettigrew, T. ve F. Tropp, L. R. (2006). A meta-analytic test of intergroup contact theory. Journal of Personality and Social Psychology, 90, 751-783.

Pettigrew, T. F. ve Tropp, L. R. (2008). How does intergroup contact reduce prejudice? Meta-analytic tests of three mediators. European Journal of Social Psychology, 38, 922-934.

Phinney, J. S. (1989). Stages of ethnic identity development in minority group adolescents. Journal of Early Adolescence, 9, 34-49.

Phinney, J. S. (1993). A three-stage model of ethnic identity development in adolescence. M. E. Knight içinde, SUNY series, United States Hispanic studies. Ethnic identity: Formation and transmission among Hispanics and other minorities (s. 61-79). Albany: State University of New York Press.

Phinney, J. S., Ferguson, D. L. ve Tate, J. D. (1997). Intergroup attitudes among ethnic minority adolescents: A causal model. Child Development, 68, 955-969.

Phinney, J. S., Jacoby, B. ve Silva, C. (2007). Positive intergroup attitudes: The role of ethnic identity. International Journal of Behavioral Development, $31,478-490$.

Psaltis, C. ve Lytras, E. (2012). Final report: Representations of past-present and future: A 3-wave longitudinal study across the divide of Cyprus (United Nations Development Programme [UNDP] için hazırlanmış yayınlanmamış rapor).

Riek, B., Mania, E. ve Gaertner, S. (2006). Intergroup threat and outgroup attitudes: A meta-analytic review. Personality and Social Psychology Review, 10, 336-353.

Riva, G., Teruzzi, T., ve Anolli, L. (2003). The use of the internet in psychological research: Comparison of online and offline questionnaires. Cyber Psychology and Behavior, 6, 73-80.

Sassenberg, K. ve Wieber, F. (2005). Don't ignore the other half: The impact of ingroup identification on implicit measures of prejudice. European Journal of Social Psychology, 35, 621-632.

Sherif, M., Harvey, O. J., White, B. J., Hood, W. R. ve Sherif, C. W. (1961). Intergroup conflict and cooperation: The Robbers Cave experiment (Cilt 10). Norman, OK: University Book Exchange.

Sniderman, P. ve Hagendoorn, L. (2007). When ways of life collide: Multiculturalism and its discontents in the Netherlands. NJ: Princeton University Press. 
Stathi, S., Husnu, S. ve Pendleton, S. (2017). Intergroup contact and contact norms as predictors of post-conflict forgiveness. Group Dynamics: Theory, Research, and Practice, 21, 20-39.

Stephan, W. G., Boniecki, K. A., Ybarra, O., Bettencourt, A., Ervin, K. S., Jackson, L. A., ... ve Renfro, C. L. (2002). The role of threats in the racial attitudes of Blacks and Whites. Personality and Social Psychology Bulletin, 28, 1242-1254.

Tajfel, H. ve Turner, J. (1979). An integrative theory of intergroup conflict. W. G. Austin ve S. Worshel (Ed.) içinde, The social psychology of intergroup relations (s. 33-37). Monterey, CA: Brooks/Cole.

Taşdemir, N. (2018). Ulusal kimliğin sınırlarını tanımlama biçimleri ve Türkiye'ye gelen suriyeli sığınmacılara yönelik tutumlar. Türk Psikoloji Yazıları, 21, 3-18.

Tausch, N., Tam, T., Hewstone, M., Kenworthy, J. ve Cairns, E. (2007). Individual-level and group-level mediators of contact effects in Northern Ireland: The moderating role of social identification. British Journal of Social Psychology, 46, 541-556.

Tausch, N., Hewstone, M., Kenworthy, J. B., Psaltis, C., Schmid, K., Popan, J. R., ... ve Hughes, J. (2010). Secondary transfer effects of intergroup contact: Alternative accounts and underlying processes. Journal of Personality and Social Psychology, 99, 282-302.

Todd, A. R., Bodenhausen, G. V. ve Galinsky, A. D. (2012). Perspective taking combats the denial of intergroup discrimination. Journal of Experimental Social Psychology, 48, 738-745.

Tunç, A. Ş. (2015). Refugee behavior and its social effects: An assessment of Syrians in Turkey. Turkish Journal of TESAM Academy, 2, 29-63.

Turner, R. N., West, K. ve Christie, Z. (2013). Out-group trust, intergroup anxiety, and out-group attitude as mediators of the effect of imagined intergroup contact on intergroup behavioral tendencies. Journal of Applied Psychology, 43, E196-E205.

Uluğ, Ö. M. ve Cohrs, J. C. (2017). How do experts differ from politicians in understanding a conflict? A comparison of track I and track II actors. Conflict Resolution Quarterly, 35, 147-172.

Ünal, S. (2014). Türkiye'nin beklenmedik konukları: Öteki bağlamında yabancı göçmen ve mülteci deneyimi [Unexpected guests of Turkey: Immigrant and refugee experiences as the other]. Zeitschrift für die Welt der Türken/Journal of World of Turks, 6, 65-89.

Verkuyten, M. (2005). Ethnic group identification and group evaluation among minority and majority groups: Testing the multiculturalism hypothesis.
Journal of Personality and Social Psychology, 88, 121-138.

Verkuyten, M. (2006). Multicultural recognition and ethnic minority rights: A social identity perspective. European Review of Social Psychology, 17, 148184.

Verkuyten, M. ve Brug, P. (2004). Multiculturalism and group status: The role of ethnic identification, group essentialism and Protestant ethic. European Journal of Social Psychology, 34, 647-661.

Verkuyten, M. ve Nekuee, S. (1999). Ingroup bias: The effect of self-stereotyping, identification and group threat. European Journal of Social Psychology, 29, 411-418.

Vescio, T. K., Sechrist, G. ve Paolucci, M. P. (2003). Perspective taking and prejudice reduction: The mediational role of empathy arousal and situational attributions. European Journal of Social Psychology, 33, 455-472.

Voci, A. ve Hewstone, M. (2003). Intergroup contact and prejudice toward immigrants in Italy: The mediational role of anxiety and the moderational role of group salience. Group Processes \& Intergroup Relations, 6, 37-54.

Vural, Y. ve Rüstemli, A. (2006). Identity fluctuations in the Turkish Cypriot community. Mediterranean Politics, 11, 329-348.

Ward, C. ve Masgoret, A. M. (2006). An integrative model of attitudes toward immigrants. International Journal of Intercultural Relations, 30, 671-682.

Webster, C. ve Timothy, D. J. (2006). Travelling to the 'other side': The occupied zone and Greek Cypriot views of crossing the Green Line. Tourism Geographies, 8, 162-181.

Wyer, N. A. (2010). Salient egalitarian norms moderate activation of out-group approach and avoidance. Group Processes \& Intergroup Relations, 13, 151165.

Zebel, S., Doosje, B. ve Spears, R. (2009). How perspective-taking helps and hinders group-based guilt as a function of group identification. Group Processes \& Intergroup Relations, 12, 61-78. 